\title{
Correction to: Q\&A: insulin secretion and type 2 diabetes: why do $\beta$-cells fail?
}

James Cantley and Frances M. Ashcroft

\section{Correction to: BMC Biol}

$$
\text { https://doi.org/10.1186/s12915-015-0140-6 }
$$

Upon publication of the original article [1], the authors noticed that they had accidently omitted to acknowledge funding from the European Research Council. The Acknowledgements should have included the sentence "We thank the European Research Council for support (grant no. 322620 to FMA)."

Received: 14 March 2019 Accepted: 14 March 2019

Published online: 09 April 2019

\section{Reference}

1. Cantley, Ashcroft. Q\&A: insulin secretion and type 2 diabetes: why do $\beta$-cells fail? BMC Biol. 2015;13:33 https://doi.org/10.1186/s12915-015-0140-6.

\footnotetext{
* Correspondence: frances.ashcroft@dpag.ox.ac.uk

Department of Physiology, Anatomy \& Genetics, University of Oxford, Parks
}

Road, Oxford OX1 3PT, UK 